\title{
MATHEMATICAL MODEL AND ALGORITHM OF SELECTING SOFTWARE PROMOTION OPTIONS DIFFERENTIATED BY FUNCTIONALITY AND BUSINESS MODELS
}

\author{
Yuriy P. YEKHLAKOV \\ Professor, Head of Department of Data Processing Automation, \\ Tomsk State University of Control Systems and Radioelectronics (TUSUR) \\ Address: 40, Lenina ave., Tomsk, 634050, Russian Federation \\ E-mail:upe@tusur.ru \\ Dmitriy N. BARAKSANOV \\ Post-graduate Student, Department of Data Processing Automation, \\ Tomsk State University of Control Systems and Radioelectronics (TUSUR) \\ Address: 40, Lenina ave., Tomsk, 634050, Russian Federation \\ E-mail:upe@tusur.ru
}

The paper focuses on issues and tasks IT companies face with when promoting proprietary software products on consumer markets. It provides the description of the basic software product market represented as a combination of specific prospective customer groups, to which a software product line with relevant functionality can be offered using different delivery business models. The authors suggest three groups of market segment attractiveness: market attractiveness, competition level and a company's performance in the segment.

The authors developed a multi-objective mathematical model for selecting options of software product distribution in selected market segments. The following selection criteria for software distribution options in selected market segments are advanced: maximum of total profit, minimum of promotion expenses, minimum of target segments number and maximum of an integrated measure of segments attractiveness. Limitations of the model include the volume of human resources in each single-discipline group of specialists in an IT company and application of a single option of software product delivery for each of market segments. An algorithm for solution of the problem relies on successive concession method. However, suggested criteria of optimization are applicable for other methods of the multi-objective problem solution.

The authors described the results of the model application for a real problem of selecting distribution options for the 'Electronic Timetable' software product for specialized secondary education and higher education institutions of Siberian Federal District in Russia. Twenty-four segments were selected for distribution, where two software distribution models were possible - «software as a service» (SaaS) and «application service provider» (ASP). Assessment of qualitative and quantitative parameters of the mathematical model was conducted by experts using optimistic, pessimistic and realistic scenarios. As a result of the problem solution, software product should be distributed as SaaS in 14 segments, and as ASP - in 3 segments. The results of the study may be useful for directors and managers of small IT companies when formulating strategies for proprietary software product distribution in certain target segments.

Key words: software product distribution, target market segmentation, target segment attractiveness, methods of multidimensional classification of objects, management of software product portfolio, multi-criterion problem of integer linear programming.

Citation: Yekhlakov Yu.P., Baraksanov D.N. (2015) Mathematical model and algorithm of selecting software promotion options differentiated by functionality and business models. Business Informatics, no. 4 (34), pp. 55-62.

DOI: $10.17323 / 1998-0663.2015 .4 .55 .62$. 


\section{Introduction}

A t present, IT companies associated with production of software products, in one way or another select one of the two activity business models: development and promotion of their own software products (product model), or development of a unique customized software product (custom model). From the developer's point of view, the product model is more promising by virtue of the fact that the company is positioned on the market as a producer of new projects and technologies. In this context, the company management is to solve such tasks as determining the boundaries of the primary software market (distinguishing target segments therein), building functionally different options of software products architectures, identifying business models of their delivery to the consumers, as well as selecting the optimal range of software delivery options for target market segments in the resource-constrained environment.

From the point of view of marketing and management $[1,2]$, these tasks can be resolved by determining a product-market matrix in the form of a variety of product offerings that meet the consumers' requirements in selected target market segments and developing a matrix-based product portfolio, providing a required balance between the producer resource capabilities, consumer needs, amount of a potential gain and expected cost. In publications related to management of IT companies, the tasks of this sort are assigned to portfolio management. Papers [3-5] describe capabilities of specific market tools to manage the project portfolios that provide information support for the basic software projects life cycle processes. Description of models and procedures to optimize software projects management is given in [6, 7]. Furthermore, the literature currently discusses an area of engineering lines of software products. For example, papers [8-10] present a policy of industrial software development, based on organization of a family (line) of software products by reusing components. Paper [11] addresses a two-stage model of generating a product line satisfying the preferences of a wide range of consumers and developing an optimal solution for release of products in demand by a certain group of consumers.

With due regard of the above approaches, this article addresses the task of launching replicated software products different in the functionality and business models of delivery to the target markets in the IT company resource-constrained environment.

\section{Description of the primary market}

The three-dimensional scheme proposed by D.Abel and improved by J.-J. Lambin [2] was taken as a basis of determining the software product primary market boundaries, where groups of potential customers, functions (consumer needs) and technologies (alternative ways of implementing the functions) were identified as the original coordinates determining the primary market. To determine the boundaries of the primary market of replicated software, it is proposed to use the following coordinate system: target market segments on which the company will concentrate its efforts differentiated with respect to the functionality of software delivery options; software delivery business model and associated services (Fig. 1).

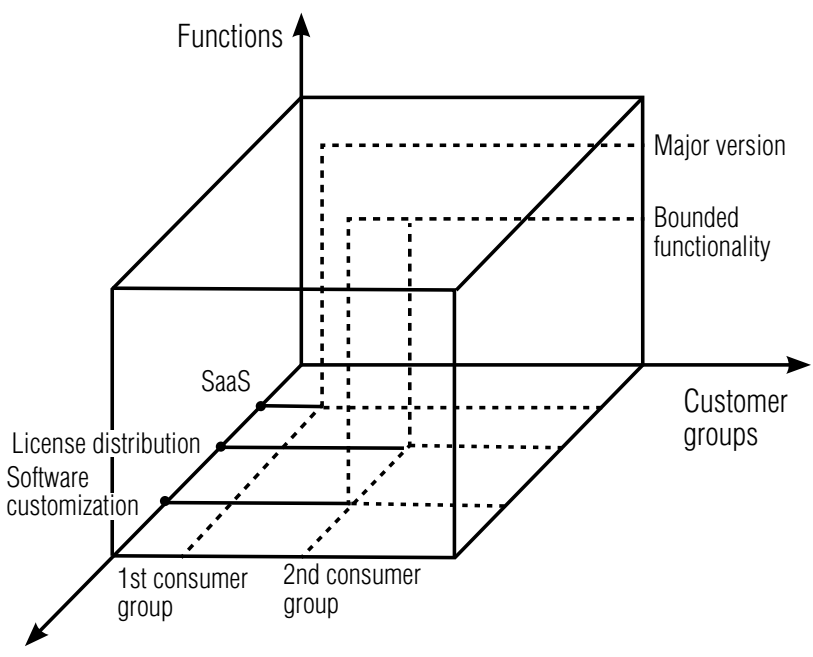

Replication Business models

Fig. 1. 3D model describing software market

For selection of target market segments and groups of potential customers both hierarchical and iterative segmentation methods [12] can be used. In so doing, in the light of specific features of software as a commodity good, the following set of characteristics as segmentation variables is proposed to be used: geographical location, type of ownership, sectoral affiliation, corporate consumer size, a list of purchased services, level of development of information and communication technologies [13].

The needs of potential consumers in each of the target segments can be satisfied through delivery of functionally differentiated software versions: major version or differentiated set of functions (depending on software configuration or integrity of its delivery). 
Free software distribution with further maintenance; distribution of licenses for box versions; Software as a Service, (SaaS); dedicated installation of the software (Application Service Provider, ASP); software customization as required by the customer can be distinguished as the main software delivery business models and associated services.

In consideration of the foregoing, a description of the software primary market can be represented as a set $S$ of certain groups of potential customers which software with functionality $F$ of interest based on a specific software delivery business model $B$ can be proposed to.

\section{Mathematical model and solution algorithm}

Let us assume that $S=\{1,2, \ldots, j, \ldots, m\}$ is a set of target market segments resulting from segmentation of consumers of the primary market; $F=\{1,2, \ldots, f, \ldots, d\}$ is a set of functionally differentiated software versions; $B=\{1,2, \ldots, b, \ldots, l\}$ is a set of software delivery business models and associated services for each of target market segments. Software delivery of a specific functionality replicated by a specific business model including a number of service applications, such as server-based version, desktop-applications, mobile applications, etc. will be identified as an alternative software delivery. The Cartesian product of the sets $F^{*} B$ forms a set of alternatives (options) of the software product delivery to the target market segments $V=\{1,2, \ldots, i, \ldots, n\}$. Then, the mathematical model of selecting software delivery options for the target market segments can be represented as follows.

Set $X=\left\{x_{i j}\right\}, i=\overline{1, n}, j=\overline{1, m}$, shall be determined, where

$$
x_{i j}=\left\{\begin{array}{l}
1, \text { if the } i \text {-th delivery option will progress } \\
\text { in the } j \text {-th target segment } \\
0, \text { if this is not the case. }
\end{array}\right.
$$

It is obvious that the selection of a specific option of software product delivery depends on the company's abilities to attract single-discipline specialists (programmers, system administrators, sales managers, support professionals, and others.) for replication processes. In this case, the restriction of a task on human resources can be represented as

$$
\sum_{i=1}^{n} \sum_{j=1}^{m} t_{i j k} \cdot x_{i j} \leq T_{k}, k=1, t
$$

where $t_{i j k}$ are required human resources (in man-hours and man-months) of the $k$-th group of single-discipline specialists to ensure replication processes of the $i$-th software delivery option in $j$-th segment;

$T_{k}$ are human resources available at the company of the $k$-th group of single-discipline specialists.

A small IT company is interested in replication of only one software delivery option to each segment:

$$
\sum_{i=1}^{n} x_{i j}=1, j=\overline{1, m} .
$$

This can enhance the quality of the product positioning in the target market segment, ensure specialization of profession-oriented corporate employees for the segment customer service and preclude the need for supporting several software delivery options. As a final result, this leads to a decrease in an overall effort to ensure the software replication processes.

It is customary that two indicators affecting the efficiency of business operations are applied as an optimality criterion in the problems of this kind:

1) maximization of accumulated profit in software replication:

$$
Z_{1}=\sum_{i=1}^{n} \sum_{j=1}^{m} p_{i j} \cdot x_{i j} \rightarrow \max ,
$$

where $P_{i j}$ is standard (desirable) profit from the $i$-th option of software delivery to $j$-th segment;

2) minimization of expenses (investments) for software promotion to target markets:

$$
Z_{2}=\sum_{i=1}^{n} \sum_{j=1}^{m} v_{i j} \cdot x_{i j} \rightarrow \min ,
$$

where $v_{i j}$ is a planned value of investments for promoting the $i$-th option of software delivery in $j$-th segment.

Furthermore, IT companies, due to limited financial and human resources, are unable to meet the requirements of the whole market, so the management task is to select a minimum number of target segments, which servicing will enable to reduce the potential cost of the product promotion:

$$
Z_{3}=\sum_{i=1}^{n} \sum_{j=1}^{m} x_{i j} \rightarrow \min
$$

The classical marketing literature $[1,2]$ points out that in order to estimate the efficiency of business operations in a particular market segment, it is reasonable to consider the qualitative characteristics of segments attraction along with the evaluation of quantitative indicators. With this in mind, an integrated indicator of the attraction of business operations as a target function can be used

$$
Z_{4}=\sum_{i=1}^{n} \sum_{j=1}^{m} w_{i j} \cdot x_{i j} \rightarrow \max ,
$$


where $w_{i j}$ is an integrated attraction of replication of the $i$-th option of software delivery in $j$-th segment.

Mathematical model (1-6) is a multi-criterion problem of the linear integer programming. Generally speaking, the dimension of problem is determined based on the amount allocated segments and proposed for replication of software delivery options.

With due regard to a high uncertainty of the initial model parameters and ambiguity of the relative importance of criteria, a method of successive concessions [14] for solution of the problem will be used, according to which local criteria are pre-ranked by a decision maker (DM) in a descending order of their relative importance. In this case, criterion $Z_{1}$, is considered to be the most important, and criteria $-Z_{2}, Z_{3}$ and $Z_{4}$ are considered to be less important.

In the first step, using expression (3) as an optimality criterion, we solve a one-criterion problem of linear programming (1-3). The resulting optimal solution of the problem (1-3) makes it possible to determine options of software delivery to specified segments with the value of expected profit $P$ In the second step the decision-maker assigns a value of allowable reduction of profit $\Delta P \geq 0$. Expression (4) is used as the optimality criterion, and expression (3) is transferred to the category of restrictions (7). A solution of one-criterion problem of linear programming $(1,2$, 4,7 ) is found:

$$
\sum_{i=1}^{n} \sum_{j=1}^{m} p_{i j} \cdot x_{i j} \geq P-\Delta P .
$$

Concession $\Delta V \geq 0$ is assigned for second criterion $Z_{2}$, expression (4) is transferred to a category of restrictions (8). The solution of one-criterion problem of linear programming $(1,2,5,7,8)$ for criterion $Z_{3}$ is found with specified concessions for the first and second criteria:

$$
\sum_{i=1}^{n} \sum_{j=1}^{m} v_{i j} \cdot x_{i j} \leq V+\Delta V,
$$

Further, concession $\Delta S \geq 0$ is made, expression (5) is transferred to a category of restrictions (9) and problem $(1,2,6-9)$ is solved using criterion $Z_{4}$. The resulting candidate solution is considered to be optimal.

$$
\sum_{i=1}^{n} \sum_{j=1}^{m} x_{i j} \leq S+\Delta S .
$$

\section{Selection and justification of the list and evaluation of the primary model indicators}

Based on the analysis and generalization of papers [15-17], the list of primary indicators for calculation of an integrated index for assessing the business operations appeal is proposed to be determined proceeding from the market appeal of target segments, software competitiveness in the target segments and capabilities of the company activity in these segments (Table 1).

Under conditions of a high degree of uncertainty for estimation of quantitative parameters of the mathematical model and qualitative indicators of the segment appeal an expert evaluation method in conjunction with PERT method [18] is proposed to be used. The evaluations of target segments appeal indicators can be determined by the experts based on optimistic o, pessimistic $\mathrm{p}$ and realistic b options (Table 2). An average evaluation of the appeal is determined by $w_{i j}^{k}=\left(w_{i j}^{o}+4 w_{i j}^{b}+w_{i j}^{p}\right) / 6$.

\begin{tabular}{|c|c|}
\hline Indicator & Indicator description \\
\hline \multicolumn{2}{|c|}{ Indicators of market appeal of target segments } \\
\hline $\begin{array}{l}\text { Segment capacity } \\
\text { and trend }\end{array}$ & $\begin{array}{l}\text { Status of growth dynamics or reduction } \\
\text { of a number of enterprises being potential } \\
\text { consumers of software }\end{array}$ \\
\hline $\begin{array}{l}\text { Information } \\
\text { infrastructure level }\end{array}$ & $\begin{array}{l}\text { Availability and quality of information services } \\
\text { at the segment enterprises }\end{array}$ \\
\hline $\begin{array}{l}\text { Expandability } \\
\text { of a range of software } \\
\text { and services }\end{array}$ & $\begin{array}{l}\text { Potential demands of enterprises in other } \\
\text { company products and services }\end{array}$ \\
\hline \multicolumn{2}{|c|}{ Indicators of software competitiveness } \\
\hline $\begin{array}{l}\text { Compliance of } \\
\text { software character- } \\
\text { istics with consumer } \\
\text { demands }\end{array}$ & $\begin{array}{l}\text { The extent of required modifications } \\
\text { (adaptation) of software to satisfy demands } \\
\text { of the segment consumers }\end{array}$ \\
\hline $\begin{array}{l}\text { Presence of software } \\
\text { competitors and } \\
\text { brand awareness }\end{array}$ & $\begin{array}{l}\text { Presence and quantity of software competitors } \\
\text { similar in performance }\end{array}$ \\
\hline $\begin{array}{l}\text { Level of software } \\
\text { uniqueness }\end{array}$ & $\begin{array}{l}\text { Available of unique advantages in software over } \\
\text { similar products. }\end{array}$ \\
\hline \multicolumn{2}{|c|}{$\begin{array}{c}\text { Indicators reflecting capability } \\
\text { of company best practice in a segment }\end{array}$} \\
\hline $\begin{array}{l}\text { Consumers } \\
\text { availability }\end{array}$ & $\begin{array}{l}\text { Company's ability to conduct necessary } \\
\text { communications with the segment } \\
\text { consumers, both in terms of software delivery } \\
\text { and subsequent maintenance }\end{array}$ \\
\hline $\begin{array}{l}\text { Technological } \\
\text { mobility of the } \\
\text { company }\end{array}$ & $\begin{array}{c}\text { Capability and speed of company response } \\
\text { to appearance of new segment players } \\
\text { and software }\end{array}$ \\
\hline $\begin{array}{l}\text { Company experience } \\
\text { in consumer } \\
\text { servicing }\end{array}$ & $\begin{array}{c}\text { The success story of the company cooperation } \\
\text { with enterprises similar to the segment } \\
\text { consumers by form of ownership, } \\
\text { company size, software implementation } \\
\text { and maintenance technology, procurement } \\
\text { specifics and other characteristics }\end{array}$ \\
\hline $\begin{array}{l}\text { Compliance with } \\
\text { strategic objectives } \\
\text { and key competence } \\
\text { of the company }\end{array}$ & $\begin{array}{l}\text { The degree of the company conformity with } \\
\text { business profile of the segment consumers }\end{array}$ \\
\hline
\end{tabular}

Table 1.

Indicators of market appeal of target segments 
The optimistic appeal assessment assumes that the segment is extremely attractive for software replication, the software product is unique, the company has highly qualified specialists, the business profitability is quite high, and occurrence of any risks is improbable. The pessimistic appeal assessment is performed if the company has many problems in the target segment, namely, presence of competitors, high cost, low level and quality of information services at the enterprises and others. A realistic assessment means that the segment is moderately attractive for software replication.

A discussion as an open panel discussion of individual appeal characteristics with the involvement of relevant company specialists and external experts (marketing specialists, analysts, investors, etc.) is proposed to be used as an expert assessment procedure. The project manager can act as a leading discussion manager. Final optimistic, most likely and pessimistic assessments are documented after reaching an opinion consistency of experts involved in the assessment.

The quantitative model parameters, profit thresholds and necessary expenditure are assessed by the same procedure, in so doing, the expert assessments consist of three numbers: minimum, maximum, and most likely values.

\section{Test case}

Let us consider the process of solving the problem of selecting options of the software product delivery «Electronic timetable» to the market of secondary and higher educational institutions of the Siberian Federal District (SFD) of Russia. The subjects forming part of SFD; types of educational institutions (university or college); size of the institution (number of study groups of students) were used as segmentation variables in differentiation of consumer groups. These segments characteris- tics were formed on the basis of reference book of federal portal «Russian Education» as of 13.01.2015 [19].

As a result of the market segmentation 24 target segments of special secondary and higher educational institutions of the Siberian Federal District (12 subjects by 2 types of educational institutions with not more than 100 study groups) were obtained. «Electronic timetable» software is planned to be replicated in two delivery business models: SaaS model with a built-in mechanism of adaptation enabling the consumers to work with a single cloud service, and ASP model representing an allocation of a standalone application for a separate educational institution with more powerful capabilities of adaptation and improvement according to the customer needs. The SaaS model can be used by colleges and universities, while the ASP model can be used by institutions only. Table 2 presents a fragment of initial data for solving the problem of selecting «Electronic timetable» software delivery options to SFD universities and colleges.

The results of the iterative solution of the problem based on the method of successive concessions are presented in Table 3. A set of «Electronic timetable» software replication options resulting from the last iteration looks like this:

1) delivery of SaaS-version: colleges and universities of the Altai Territory; colleges of Zabaikalye Territory; colleges and higher educational institutions of Irkutsk region; colleges and universities of Kemerovo region; colleges and universities of Krasnoyarsk Territory; colleges and universities of Novosibirsk Region; colleges of Omsk region; colleges of the Republic of Buryatia; colleges Tomsk region.

2) delivery of ASP-version: universities of Omsk region; universities of the Republic of Buryatia; universities of Tomsk region.

Table 2.

Characteristics of options of «Electronic timetable» software delivery to universities and colleges of the Siberian Federal District

\begin{tabular}{|c|c|c|c|c|c|c|c|c|c|c|c|c|c|c|c|}
\hline \multirow[t]{2}{*}{ Subject of SFD } & \multicolumn{3}{|c|}{ Appeal } & \multicolumn{3}{|c|}{$\begin{array}{c}\text { Profit, } \\
\text { thousand rubles }\end{array}$} & \multicolumn{3}{|c|}{$\begin{array}{l}\text { Expenses } \\
\text { for promotion } \\
\text { thousand rubles }\end{array}$} & \multicolumn{2}{|c|}{$\begin{array}{l}\text { Technicians, } \\
\text { man-hours }\end{array}$} & \multicolumn{4}{|c|}{$\begin{array}{c}\text { Project Manager, } \\
\text { man-hours }\end{array}$} \\
\hline & 1 & 2 & 3 & 1 & 2 & 3 & 1 & 2 & 3 & 1,2 & 3 & 1 & 2 & 1,2 & 3 \\
\hline Altai territory & 7,9 & 8 & 8,5 & 78,4 & 29,4 & 47,6 & 33,6 & 12,6 & 20,4 & \multirow{4}{*}{300} & 500 & 40 & 15 & \multirow{4}{*}{96} & 124 \\
\hline Novosibirsk region & 8 & 8,1 & 8,6 & 98 & 29,4 & 47,6 & 42 & 12,6 & 20,4 & & 500 & 50 & 15 & & 124 \\
\hline$\vdots$ & & & & & & & & & & & & & & & \\
\hline Tomsk region & 7,8 & 8,2 & 8,7 & 39,2 & 19,6 & 23,8 & 16,8 & 8,4 & 10,2 & & 250 & 20 & 10 & & 62 \\
\hline
\end{tabular}


Table 3 .

Results of incremental solution of problems

for selecting «Electronic timetable» software delivery options

\begin{tabular}{|c|c|c|c|c|c|c|}
\hline \multirow[b]{2}{*}{ Criteria } & \multicolumn{6}{|c|}{ INDIGATORS } \\
\hline & $\begin{array}{l}\text { Number } \\
\text { of delivery } \\
\text { options }\end{array}$ & $\begin{array}{l}\text { Average } \\
\text { appeal }\end{array}$ & $\begin{array}{l}\text { Expeoted profit, } \\
\text { thousand rubles }\end{array}$ & $\begin{array}{l}\text { Expected expens- } \\
\text { es for promotion, } \\
\text { thousand rubles }\end{array}$ & $\begin{array}{l}\text { Required human } \\
\text { resources of } \\
\text { technicians, man hour }\end{array}$ & $\begin{array}{l}\text { Required human } \\
\text { resourees of project } \\
\text { managers, man hour }\end{array}$ \\
\hline 1. Profit maximization & 22 & 7,79 & 559,9 & 417 & 1050 & 742 \\
\hline $\begin{array}{l}\text { 2. Minimization } \\
\text { of expenses for promotion }\end{array}$ & 20 & 7,74 & 501,1 & 391,8 & 1050 & 712 \\
\hline $\begin{array}{l}\text { 3. Minimization of a } \\
\text { number of target segments }\end{array}$ & 17 & 7,8 & 501,1 & 391,8 & 1050 & 712 \\
\hline $\begin{array}{l}\text { 4. Maximization } \\
\text { of average appeal }\end{array}$ & 17 & 7,87 & 505,3 & 393,6 & 1300 & 764 \\
\hline
\end{tabular}

The analysis of the incremental selection of «Electronic timetable» software delivery options enables to conclude that a number of selected segments (from 22 to 17 ) is changed in various iterations of solving the problem. The results obtained in the second and third steps show that while minimizing a number of segments the expected profit and expenses remain unchanged, and the amount of human resources increases. This may be due to the fact that at these algorithm stages segments with a large number of educational institutions are selected. A decrease of the expected profit to expense ratio (from 1.34 to 1.28) is observed between the first and the second steps, however, in the next steps this ratio is stabilized, at this, a steady growth of the average segments appeal indicator is observed from the third step.

\section{Conclusion}

A description of the primary software market in the form of a three-dimensional model (consumers, functionality, delivery business model) enables to create a base set of software delivery options and prioritize de- livery options based on the company's own capabilities and specifics of the market of potential users. The four optimality criteria proposed in the article make it possible to describe the problem of selecting functionalityand business model-differentiated options for software delivery in the form of alternative models, and use other methods of solving multi-criteria problems. In addition, the proposed model of volume planning of selection of software delivery options to the target market segments can be modernized in a volume-scheduling model that accounts for software time intervals of delivery (for example, year, quarter, month).

The analysis of the results of selecting options of the «Electronic timetable» software delivery to the market of specialized secondary and higher educational institutions of the Siberian Federal District makes it possible to conclude about the suitability of the proposed model and algorithm for solving practical problems. The problem solving results may be useful to directors and managers of small IT companies in forming replication strategies for their own software products to prospective target segments.

\section{References}

1. Webster F. (2005) Osnovy promyshlennogo marketinga [Fundamentals of industrial marketing]. Moscow: Grebennikov Publishing House (in Russian).

2. Lambin J.-J. (2007) Menedzhment, orientirovannyj na rynok. Strategicheskij i operacionnyj marketing [Market oriented management. Strategic and operational marketing]. St.Petersburg: Piter (in Russian).

3. Chulani S., Santhanam P., Hodges B., Anders K. (2007) Metriki upravlenija portfelem programmnyh produktov [Metrics-based management of software product portfolios]. Open Systems, no. 3. Available at: http://www.osp. ru/os/2007/03/4177900/ (accessed 9 February 2012) (in Russian).

4. Dubova N. (2008) Upravlenie s portfelem [Management with portfolio]. Open Systems, no. 3. Available at: http://www.osp.ru/os/2008/03/5015107/ (accessed 9 February 2012) (in Russian).

5. Oganesyan A. (2008) Opyt upravlenija portfelem IT-proektov [Experience of managing a portfolio of IT projects]. Open Systems, no. 3. Available at: http://www.osp.ru/os/2008/03/5015181/ (accessed 9 February 2012) (in Russian).

6. Avdoshin S.M., Lifshits A.A. (2014) Formirovanie portfelja proektov na osnove nechetkoj modeli mnogokriterial'noj optimizacii [Project portfolio formation based on fuzzy multi-objective model]. Business Informatics, no. 1 (27), pp. 14-22 (in Russian). 
7. Nedovesov M.V., Rudenko Z.G. (2012) Formirovanie optimal'nogo portfelja vzaimozavisimyh proektov i ego optimizacija po vremeni [Optimal portfolio of interdependent projects construction and time optimization]. Control Sciences, no. 4, pp. 26-31 (in Russian).

8. Kang K., Lee J., Donohoe P. (2002) Feature-oriented product line engineering. IEEE Software, July/August, pp. 58-65.

9. Koznov D.V., Novickij I.A., Smirnov M.N. (2013) Instrumenty dlja upravlenija variantivnost'ju: gotovnost' k promyshlennomu primeneniju [Variability management tools: Readiness for industrial use]. SPIIRAS Proceedings, no. 3 (26), pp. 297-331 (in Russian).

10.Guss S.V. (2011) Razrabotka semejstva programmnyh sistem v specificheskoj predmetnoj oblasti [The development of a family of software systems in a particular subject area]. Mathematical Structures and Modeling, no. 22, pp. 55-68 (in Russian).

11. Michalek J.J., Ebbes P., at all. (2011) Enhancing marketing with engineering: Optimal product line design for heterogeneous markets. International Journal of Research in Marketing, no. 28, pp. 1-12.

12. Kosterin A.G. (2002) Praktika segmentirovanija rynka [The practice of market segmentation]. St.Petersburg: Piter (in Russian).

13. Yekhlakov Yu.P., Baraksanov D.N., Mamonova N.V. (2012) Funkcional'naja i matematicheskie modeli segmentirovanija rynka programmnyh produktov [Functional and mathematical models of segmentation consumers of software]. St.Petersburg State Polytechnical University Journal. Computer Science. Telecommunications. Control Systems, no. 2, pp. 155-160 (in Russian).

14. Podinovsky V.V., Gavrilov V.M. (1975) Optimizacija po posledovatel'no primenjaemym kriterijam [Optimization on consistently applied criteria]. Moscow: Sovetskoe radio (in Russian).

15. Wood M.B. (2007) Marketingovyj plan. Prakticheskoe rukovodstvo po razrabotke [The marketing plan: A handbook]. Moscow: Williams (in Russian).

16. Analiz assortimenta s pomosh ju matricy McKinsey - General Electric [Analysis of the range using the McKinsey General Electric matrix]. Available at: http://powerbranding.ru/biznes-analiz/matrica-mckinsey/ (accessed 20 June 2014) (in Russian).

17. Chto takoe privlekatel'nost' rynka i kak ee ocenit'? [What is the attractiveness of the market and how to evaluate it?]. Available at: http://powerbranding.ru/rynok/ocenka-privlekatelnosti/ (accessed 20 June 2014) (in Russian).

18. Fatrell R.T., Shafer D.F., Shafer L.I. (2004) Upravlenie programmnymi proektami. Dostizhenie optimal'nogo kachestva pri minimume zatrat [Software project management. Achieving optimal quality at the lowest cost]. Moscow: Williams (in Russian).

19. Rossijskoe obrazovanie: Spravochnik [Russian education: A reference book]. Available at: http://www.edu.ru/ (accessed 09 February 2015) (in Russian).

\section{МАТЕМАТИЧЕСКАЯ МОДЕЛЬ И АЛГОРИТМ ВЫБОРА ДИФФЕРЕНЦИРОВАННЫХ ПО ФУНКЦИОНАЛУ И БИЗНЕС-МОДЕЛЯМ ПОСТАВКИ ВАРИАНТОВ ПРОГРАММНОГО ПРОДУКТА}

\section{Ю.П. ЕХЛАКОВ}

доктор технических наук, профессор, заведующий кафедрой автоматизации обработки информации, Томский государственный университет систем управления и радиоэлектроники (ТУСУР)

Адрес: 634050, г. Томск, пр. Ленина, д. 40

E-mail: upe@tusur.ru

Д.Н. БАРАКСАНОВ

аспирант кафедры автоматизации обработки информации, Томский государственный университет систем управления и радиоэлектроники (ТУСУР) Адрес: 634050, г. Томск, пр. Ленина, д. 40

E-mail:bdn@tusur.ru 
В статье рассматриваются проблемы и задачи, с которыми сталкиваются ИТ-компании при продвижении на рынок собственных разработок. Представлено описание базового рынка программных продуктов (ПП) в виде совокупности определенных групп потенциальных потребителей, которым можно предложить линейку ПП с интересующим их функционалом по различным бизнес-моделям поставки. Предложены три группь показателей привлекательности сегментов рынка - рыночной привлекательности, уровня конкуренции, эффективности работы компании в сегменте.

Разработана многокритериальная математическая модель выбора вариантов тиражирования ПП в выделенных сегментах рынка. В качестве критериев оптимальности выделены максимум суммарной прибыли, минимум затрат на продвижение, минимум количества целевых сегментов и максимум интегрального показателя привлекательности сегментов. Ограничения модели - объемы трудовых ресурсов по каждой группе узкопрофильных специалистов ИТ-компании и поставка в каждый из сеглентов только одного варианта ПП. В качестве алгоритма решения задачи применяется метод последовательных уступок, однако предложенные критерии оптимальности позволяют использовать и другие методы решения многокритериальной задачи.

Описаны результаты использования модели на примере реальной задачи выбора вариантов поставки ПП «Электронное расписание занятий» на рынок средних спещиальных и высших учебных заведений Сибирского федерального округа Российской Федераџии. Для тиражирования выделены 24 сегмента, потребителям которых предлагается поставка ПП по двум бизнес-моделям: «Software as a service» (SaaS) u «application service provider» (ASP). Оиенка количественных и качественных параметров математической модели проведена экспертами по оптимистическому, пессимистическому и реалистическому сценариям. Результаты решения задачи: ПП по модели SaаS предлагается тиражировать в 14 сеглентах, по модели ASP-в 3 сегментах. Полученные результать могут быть полезны руководителям и менеджерам небольших ИТ-компаний при формировании стратегий тиражсирования собственных программных продуктов в перспективных целевых сегментах.

Ключевые слова: тиражирование программного продукта, сегментация рынка потенциальных потребителей, привлекательность целевых сегментов, методы многомерной классификации объектов, управление портфелем программных продуктов, многокритериальная задача целочисленного линейного программирования.

Цитирование: Yekhlakov Yu.P., Baraksanov D.N. Mathematical model and algorithm of selecting software promotion options differentiated by functionality and business models. Business Informatics. 2015. No. 4 (34). P. 55-62.

DOI: $10.17323 / 1998-0663.2015 .4 .55 .62$.

\section{Литература}

1. Уэбстер Ф. Основы промышленного маркетинга. М.: Изд. дом Гребенникова, 2005. 416 с.

2. Ламбен Ж.-Ж. Менеджмент, ориентированный на рынок. Стратегический и операционный маркетинг / Пер. с англ. СПб.: Питер, 2007. $800 \mathrm{c}$.

3. Метрики управления портфелем программных продуктов / Б.Ходжес [и др.] // Открытые системы. 2007. № 3. [Электронный ресурс]: http://www.osp.ru/os/2007/03/4177900/ (дата обращения 09.02.2015).

4. Дубова Н. Управление с портфелем // Открытые системы. 2008. № 3. [Электронный pecypc]: http://www.osp.ru/os/2008/03/5015107/ (дата обращения 09.02.2015).

5. Оганесян А. Опыт управления портфелем ИТ-проектов // Открытые системы. 2008. № 3. [Электронный pecypc]: http://www.osp.ru/ os/2008/03/5015181/ (дата обращения 09.02.2015).

6. Авдошин С.М., Лифшиц А.А. Формирование портфеля проектов на основе нечеткой модели многокритериальной оптимизации // Бизнес-информатика. 2014. № 1 (27). С. 14-22.

7. Недовесов М.В., Руденко 3.Г. Формирование оптимального портфеля взаимозависимых проектов и его оптимизация по времени // Проблемы управления. 2012. № 4. С. 26-31.

8. Kang K., Lee J., Donohoe P. Feature-oriented product line engineering // IEEE Software. July/August 2002. P. $58-65$.

9. Кознов Д.В., Новицкий И.А., Смирнов М.Н. Инструменты для управления вариантивностью: готовность к промышленному применению // Труды СПИИРАН. 2013. № 3 (26). С. 297-331.

10. Гусс С.В. Разработка семейства программных систем в специфической предметной области // Математические структуры и моделирование. 2011. № 22. С. 55-68.

11. Michalek J.J., Ebbes P., at all. Enhancing marketing with engineering: Optimal product line design for heterogeneous markets // International Journal of Research in Marketing. 2011. No. 28. P. 1-12.

12. Костерин А.Г. Практика сегментирования рынка. СПб.: Питер, 2002. 288 с.

13. Ехлаков Ю.П., Бараксанов Д.Н., Мамонова Н.В. Функциональная и математические модели сегментирования рынка программных продуктов // Научно-технические ведомости СПбГПУ. Информатика. Телекоммуникации. Управление. 2012. № 2. С. 155-160.

14. Подиновский В.В., Гаврилов В.М. Оптимизация по последовательно применяемым критериям. М.: Советское радио, 1975.192 с.

15. Вуд М.Б. Маркетинговый план. Практическое руководство по разработке. М.: Вильямс, 2007. 352 с.

16. Анализ ассортимента с помощью матрицы McKinsey - General Electric [Электронный pecypc]: http://powerbranding.ru/biznes-analiz/ matrica-mckinsey/ (дата обращения 20.06.2014).

17. Что такое привлекательность рынка и как ее оценить? [Электронный pecypc]: http://powerbranding.ru/rynok/ocenka-privlekatelnosti/ (дата обращения 20.06.2014).

18. Фатрелл Р.Т., Шафер Д.Ф., Шафер Л.И. Управление программными проектами. Достижение оптимального качества при минимуме затрат. М.: Вильямс, 2004. 1136 с.

19. Российское образование: справочник. [Электронный pecypc]: http://www.edu.ru/ (дата обращения 09.02.2015). 